\title{
Funding for Defence
}

\author{
Peter Cozens ${ }^{1}$
}

The superior man, when resting in safety, does not forget that danger may come. When in a state of security he does not forget the possibility of ruin. When all is orderly, he does not forget that disorder may come. Thus his person is not endangered, and his States and all their clans are preserved.

\section{Confucius}

Chinese philosopher \& reformer (551 BC - 479 BC)

\section{Introduction}

The Roman statesman Cicero once said that "endless money forms the sinews of war". It is perhaps just as well that the New Zealand Defence Force is not endowed with such largesse otherwise one might have to contemplate a permanently fractious state of affairs. Nonetheless, if the nation is to utilise a Defence Force it is axiomatic that it is properly equipped, sustained, managed and commanded for the various missions it is intended to perform.

The catalyst for writing this article was the government's announcement of the Defence Sustainability Initiative (DSI) in May 2005. This entails a commitment to invest some $\$ 4.6$ billion of extra funding over a period of 10 years into the Defence budget. This article provides an overview of the significant twists and turns of defence policy over the past twenty years and supplies some answers to the question of why the DSI became necessary and what it is expected to achieve.

\section{Differing policy approaches}

In broad terms, there are three distinct periods of differing attitudes to defence policy aligned with the Lange, Bolger and Clark-led administrations:

a. The End of ANZUS (1985 - 1991); b. A Peace Dividend (1991 - 1999); and

c. A Joint Force (1999 - 2005).

What follows is a short commentary on the first period, a more detailed discussion concerning the effects of reduced Defence budgets during the second period and finally, a broad examination of significant policy announcements and initiatives during the Clark-led administration.

\section{The end of ANZUS}

Writing in a recent issue of the New Zealand International Review, Dick Gentles (2005, p.7), a former Deputy Secretary of Defence, states that the Labour government under David Lange in the mid 1980s made significant changes to New Zealand's defence policy before the end of the Cold War in 1989 to:

a. include anti-nuclear policies in New Zealand's defence posture;

b. assert an independent voice in security matters and not to be inhibited by alliance arrangements; and

c. refocus defence on the South Pacific.

These measures were articulated in the 1987 Defence White Paper. Gentles $(225$, p.8) suggests that there was a suspicion by the Lange-led administration that the New Zealand Defence Force had been shaped and equipped to suit the requirements of allies rather than to meet New Zealand's place in the South Pacific. It is not the intention to comment on the politics of the consequent fracturing of the ANZUS alliance. However, in a practical sense, it resulted in a reduction of support from the US in the form of intelligence cooperation, operations with US forces and logistic support for the New Zealand Defence Forces.

The author appreciates the assistance of Jim Olsen of the Ministry of Defence with the preparation of the quantitative data. 
The senior leadership of Defence who had coped with the demands of the Cold War were apparently hostile to the ambitions of the new political direction. Deep suspicions developed between the government and the senior echelons of Defence. Caught in the middle as these titans confronted one another in the change from one military posture to another, the New Zealand Defence Force suffered a detrimental loss of military capability and effectiveness.

\section{A peace dividend}

The end of the Cold War in 1989 heralded for many the potential for a welcome reduction in expenditures for Defence - the so-called peace dividend. This idea seemed to pervade political thinking during the Lange and Bolger administrations and appeared to be reflected in reduced budgets (see Figure 1). A popular misconception is the notion that a peace operation force would cost less than a war-fighting or combat capable force. It is probably true that equipment needs may differ slightly for peacekeeping activities and would therefore be in addition to those required for fully combat capable activities. This places an extra burden on the budget. Nevertheless, professional military advice is that peace operations to be successful can only be performed by properly prepared, well led, fully equipped, comprehensively trained and combat capable armed service professionals. These operations are usually dangerous and complex missions - the recent deployments to East Timor underscores this contention.

Contributions to peace operations by the New Zealand Defence Force during the past 15 years or so include East Timor, Bougainville, Bosnia, Iraq, Afghanistan, the Arabian Sea, Solomon Islands, Cambodia and several others besides. The New Zealand armed services have performed with distinction in all these missions - for example, the Australian Commander of the East Timor operation, General Peter Cosgrove, publicly stated his approbations. Nonetheless, it underscores the line of reasoning that appropriate resources are required to raise and sustain the armed services whatever their missions may be.

To compound a generally declining fiscal situation for Vote:Defence as a consequence of the Lange administration's policies, the incoming National government in 1990 accepted that New Zealand did not face a direct military threat and thus spending on
Defence could be reduced. The Bolger administration cut funding to Vote:Defence, according to Gentles (2005), by some $18 \%$ in real terms and significant major re-equipment plans were shelved during its first term. In its third term of office, the administration produced the 1997 Defence White Paper; this included a longterm investment plan - but because of a subsequent change in government it was not implemented.

\section{The effect of reduced Defence budgets}

During the course of the final decade of the 20th century, different political perceptions of the role of the New Zealand Defence Force - caused in part by the end of the Cold War, the fracturing of ANZUS, peacekeeping operations and an estranged defence relationship with the US - resulted in lower budgets and investment in defence operations and infrastructure. Complicating this situation was the ANZAC ship project, a scheme to reequip the Royal New Zealand Navy with new combat capable ships at a cost of approximately $\$ 500$ million each. Two ships were ordered by the Lange-led administration. This had damaging effects within Defence where it promoted bitter and acrimonious competition between the three armed services each of which wanted to maintain or even extend its share of an ever-diminishing pool of resources.

Compromising the previous duality of responsibility, the Defence Act of 1990 divided Defence Headquarters into the Ministry of Defence under the Secretary of Defence and the New Zealand Defence Force under the command of the Chief of Defence Force. The two institutions were intended to provide contestable advice to the Minister of Defence. But a disagreeable outcome of this arrangement was a "them and us" mentality that impeded good management and the optimum allocation of sparse resources to best effect.

Figure 1 illustrates the general downward trend of the defence budget in the latter stages of the Lange-led government to 1990, a further decline during the first two terms of the Bolger administration and since the low point of $1996 / 7$ a period of recovery.

During the first term of the Bolger administration, each of the three armed services, as part of a centrally directed policy initiative, sought to move resources "from the tail to the teeth" and to employ and reduce any "fat" in the system in the interests of fiscal 
Figure 1. Defence Expenditure 1988/89 - 2005/06

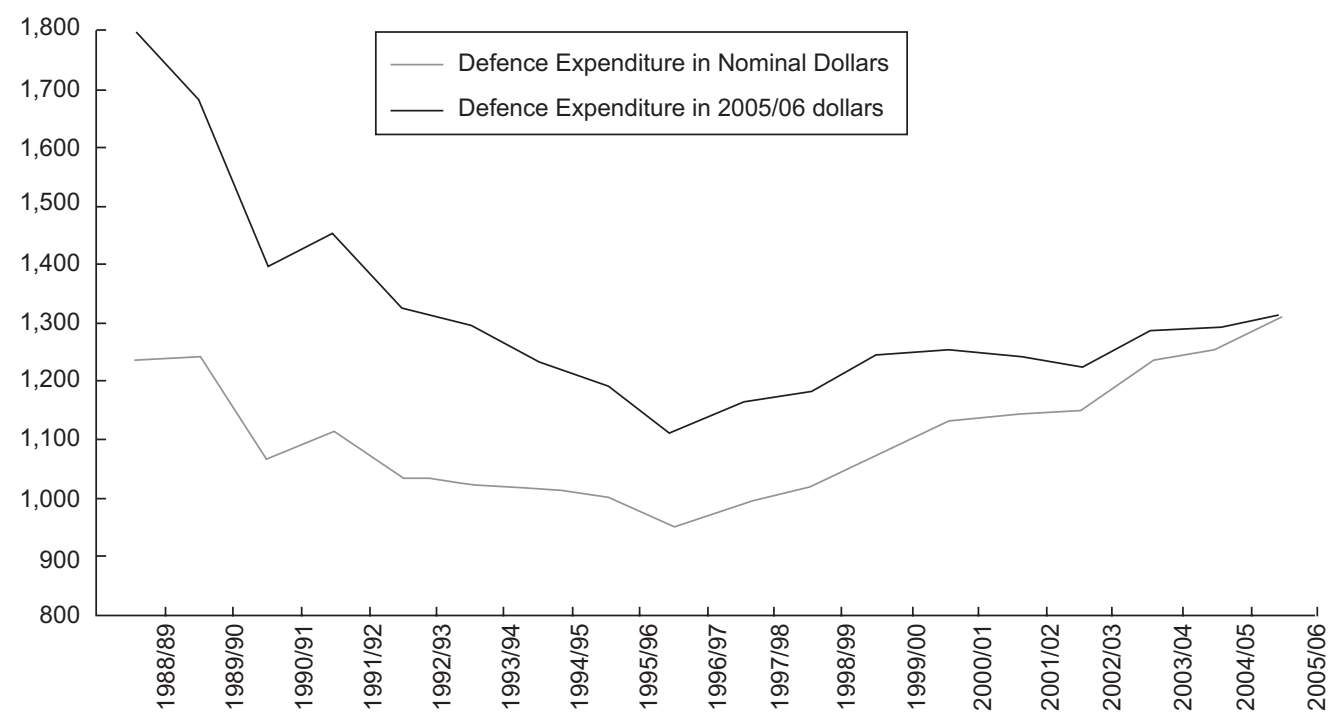

Source: Ministry of Defence, Wellington.

efficiency and effectiveness. Unfortunately, uncooperative attitudes between the three services as they each sought resources for their own projects impeded and deferred important decisions of capital procurements. Rather than promoting a more cohesive and coherent military force, these policies and the division of the Defence Headquarters into separate entities tended to produce an "isolationist mentality" within Defence itself and to inculcate a sense of severe distrust with the ambitions of outside agencies, in particular, the Treasury. Not assisting the cause of prudent and effective allocation of resources within Defence were the apparently bewildering and rapid changes occasioned by the economic reforms introduced by Roger Douglas in the mid-to-late 1980s and Ruth Richardson in the early 1990s.

In August 1999, Parliament's Foreign Affairs and Defence Select Committee, under the chairmanship of Derek Quigley, produced a report entitled Inquiry into Defence Beyond 2000. It was extremely critical of the Bolger government's approach to the whole question of Defence. In terms of fiscal impact, there were two significant implications for the future:

a. a focus on operations in the South Pacific, and;

b. a reduction in war-fighting capacity in favour of peace operations.

\section{A joint force}

The incoming centre-left administration led by Helen Clark in 1999 accepted the broad thrust of Derek Quigley's report and in June 2000 the new administration issued its Defence Policy Framework based on that assessment. A précis of the five objectives follows:

a. to defend New Zealand and to protect its people, land, territorial waters, EEZ, natural resources and critical infrastructure;

b. to meet our alliance commitments to Australia by maintaining a close defence partnership in pursuit of common security interests;

c. to assist in the maintenance of security in the South Pacific and to provide assistance to our Pacific neighbours;

d. to play an appropriate role in the maintenance of security in the Asia-Pacific region, including meeting our obligations as a member of the Five Power Defence Arrangement; and

e. to contribute to global security and peacekeeping through participation in the full range of UN and other appropriate multilateral peace support and humanitarian relief operations. 
Nearly a year later the government announced its intentions to re-shape the New Zealand Defence Force. It appreciated that because of previously reduced investments in Defence, resources were spread too thinly across a range of capabilities, thus compromising overall military effectiveness. Several reductions in force structure followed, including the axing of the air combat fighter force, but not necessarily as a consequence of any specific public strategic review or White Paper assessments. Nonetheless, the government stated that the key components of the New Zealand Defence Force would be:

a. a joint approach to structure and operational orientation;

b. a modernised Army;

c. a practical Navy fleet matched to New Zealand's wider security needs,

d. a refocused and updated Air Force; and

e. a funding commitment to provide financial certainty.

This particular policy initiative of a "joint" approach was intended to remove much of the previously destructive tribalism and to enhance cooperation between the three services. The recognition of "a funding commitment to provide financial certainty" was a significant appreciation of the previous handicap affecting the complexities of defence organisation and planning. These two firm policy directions provided opportunities for a more coherent New Zealand "profession of arms" as a consequence - cooperation rather than competition has obvious merit.

\section{The Long-Term Development Plan}

In 2002 the government introduced its Long Term Development Plan (LTDP) a planning tool to assist decision-making in respect of defence policy objectives but with a significant focus on major weapon systems and capabilities. The new scheme included provision for an injection of an extra $\$ 1$ billion over 10 years.

The LTDP is a dynamic instrument that was updated in June 2003 and again in November 2004 but with an ability to accommodate other changes. Such inbuilt flexibility is a vital part of defence readiness and potency. A significant feature of the LTDP is to enhance confidence that new major capability projects will be well managed and that acquisition schemes are consistent with the government's defence policy. Procedures are therefore incorporated in the LTDP to achieve capability development and implementation on a robust and sustainable basis. The plan includes nonfinancial descriptions of projects, their "Policy Value", "Capability Gaps", "Links to other Capabilities", plus the all-important details of costs. Irrespective of whether there are disagreements over the actual acquisitions under consideration from a strategic or security perspective, the LTDP provides some certainty as previously proposed in the government's May 2001 Statement on Defence.

Some examples of the major re-equipment programme for the armed services include the following plans. Project Protector is a scheme to acquire one multi-role vessel, two offshore and four inshore patrol vessels, to be operated by the Royal New Zealand Navy. These ships will conduct tasks for and with New Zealand Customs, the Department of Conservation, the Ministry of Agriculture and Forestry, the Ministry of Foreign Affairs and Trade, the Ministry of Fisheries, the Maritime Safety Authority of New Zealand and the New Zealand Police Force. This indicates an integrated whole-ofgovernment approach to security management in the seas around New Zealand and beyond. The inshore patrol vessels will operate around the New Zealand coast throughout the year. The offshore ships, capable of operating naval helicopters, will conduct maritime operations throughout New Zealand's EEZ and the Southern Ocean and also be used to assist Pacific Island states to patrol their EEZs. The multi-role vessel will provide a sealift facility for 250 troops, operate two naval helicopters and have an ability to transfer cargo and personnel ashore when port facilities are not available. It can also be used for disaster relief especially in the South Pacific islands after cyclones and other natural catastrophes. The government endorsed a project budget of $\$ 500$ million.

The six P3K Orion aircraft of the Royal New Zealand Air Force are to be provided with substantial upgrades. This includes the replacement of the data management, sensor, communications and navigation systems, and the provision of associated ground systems - with a cost of some \$150-220 million for mission systems upgrade and \$60-100 million for the communications/ navigation systems upgrade. 
The five $\mathrm{C} 130 \mathrm{H}$ Hercules aircraft operated by the Royal New Zealand Air Force are to have a life extension programme. This entails the replacement of specific mechanical, avionic and structural components, and the design and installation of flight deck communications and navigation improvements to meet evolving air traffic management regulations. The cost is estimated at $\$ 100$ 170 million, plus a further $\$ 100-150$ million for the communications/navigation system upgrade.

The New Zealand Army acquired the first tranche of 188 Pinzgauer Light Operational Vehicles (LOVs) out of a programmed total of 321 in October 2004 to replace the ageing Landrovers. The cost is estimated at $\$ 60$ $\$ 110$ million. This includes the vehicles, training, publications, specialist test and tools equipment, spare parts and project management costs.

These major re-equipment plans indicate a serious commitment to ensuring that the New Zealand Defence Force has the hardware to be able to perform the tasks demanded by government policy.

\section{The Review of Accountabilities and Structural Arrangements}

In addition to the LTDP the Clark-led administration also sought to improve the performance of Defence itself. This was an important measure to improve cooperation not only between the three armed services but also between civilian and military personnel within and between both organisations. There had previously been an unhelpful culture between the two institutions that precluded cooperation between some military officers and their civilian counterparts. The government therefore commissioned the Review of Accountabilities and Structural Arrangements (RASA), also known as the Hunn Review, which was published in September 2002. It aimed to improve not only the quality of strategic advice but also to improve cooperation, consultation and consensus building between the three services as well as with and between civilian staff. The review criticised the division of Defence into the Ministry of Defence and the New Zealand Defence Force as occasioned by the Defence Act 1990 saying that "the defence management system ... has not worked as well in practice as was hoped when it was first designed". Recommended changes included a revision of the Act itself to provide "shared responsibilities between the Secretary of Defence and the Chief of Defence Force to manage an integrated defence process". That recommendation has not been instituted. However, the RASA has certainly had a significant effect elsewhere.

In 2004 the government introduced the Capability Management Framework to replace the cumbersome Defence Planning System as part of its ongoing performance improvements. The new methodology was designed to improve transparency of the governance and management of long-term investments in Defence. It has also proved to be part of the foundation of what was to become the Defence Sustainability Initiative in 2005.

\section{The Defence Capability and Resourcing Review}

The events of $9 / 11$ and other international turbulence during the past seven or eight years have committed the New Zealand Defence Force to operate at a much higher tempo. This has had an effect on the resilience and power of the armed services to maintain operational effectiveness. One outcome of increased activity was the exposure of significant deficiencies within the infrastructure of Defence as a whole. The government decided to investigate the problem and in December 2003 the Ministers of Defence, Finance and State Services directed a multi-agency team to produce the Defence Capability and Resourcing Review (DCARR).

In 2004 the DCARR team conducted an exhaustive survey to establish the contemporary operating environment of the New Zealand Defence Force and its likely future requirements. The reviewers also examined the ability of the Ministry of Defence to provide policy advice. Arising from these studies the review team produced a report identifying specific shortfalls of capability, capacity and output issues but also a 10-year plan to restore them to the levels required. It may seem that 10 years is a long time in which to achieve these ambitions - however, it must be appreciated that the armed forces are comprised of people many of whom require lengthy and sophisticated training plus experience to be militarily proficient.

The review team identified a significant decline in total staff numbers, comprised of both military and civil personnel, from 20,785 in June 1991 to 12,889 in June 2004 , an overall loss of about $40 \%$. Although other parts of the economy may benefit from the acquisition of well-trained and capable personnel, the effect on the New Zealand Defence Force has been to place extra 
strain on recruitment and training, thus detracting from operational potency. Figure 2 illustrates the downward trend of personnel numbers in Defence between 1990 and 2005. at the expense of others often characterised the relationship resulting in less than optimal outcomes. It is not known who decided to insert the State Services Commission into the process of the DCARR, but this

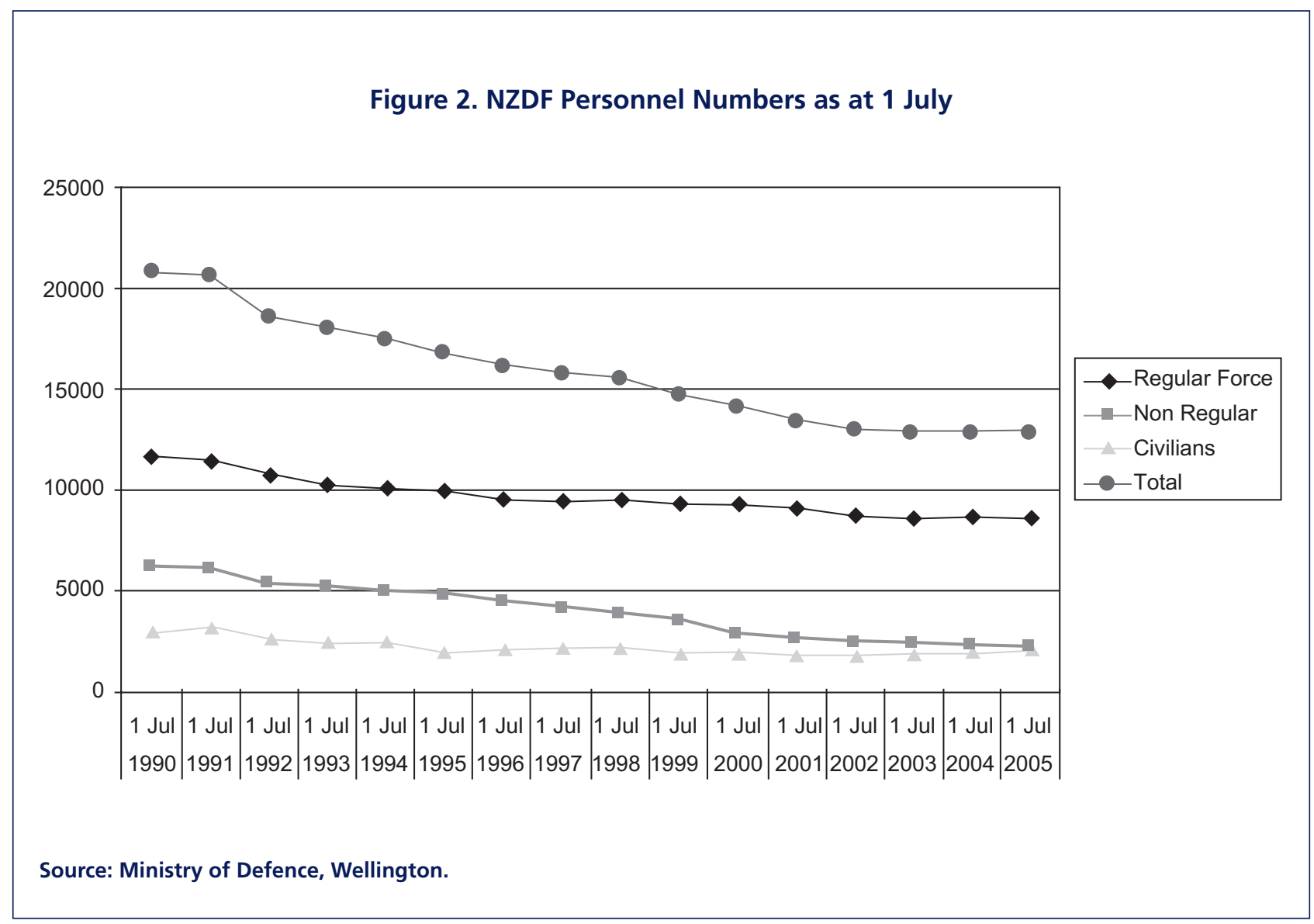

Another latent but equally negative effect on the mission capability of the New Zealand Defence Force arising from the increased tempo of operations was the effect on families of service personnel. Personnel returning from an extensive deployment overseas were sometimes required to re-engage in the same or another theatre of operations after only a short period of recuperation at home. The consequent stress on families often resulted in well trained, experienced and competent personnel making a choice to terminate their military careers. One means of correcting this problem is to increase the number of personnel under arms and to rotate them through a more measured series of operations, retraining and upskilling.

In the past, relations between the Treasury and Defence were not always constructive. Obfuscation, secondguessing, personal meddling and single service agendas piece of ingenuity, together with the new joint approach, appears to have had a beneficial effect by helping the two traditional protagonists to be more focussed on producing optimal outcomes. The review team concluded that as a result of many years of underinvestment, and notwithstanding the intentions of the LTDP, the capacity and capability of the New Zealand Defence Force and the Ministry of Defence in some very important areas were below the requirements of government policy. It was noted, for instance, that:

a. personnel numbers in the New Zealand Defence Force are below required levels;

b. in some trades the number of personnel and their trained state is deficient;

c. some major weapons platforms require upgrading or replacement; 
d. some military equipment no longer meets the required standard;

e. contingency reserve stocks of ammunition, fuel and spares are depleted;

f. there is a backlog of maintenance and capital expenditure in Defence real estate; and

g. aspects of corporate management capability are depleted.

The review team acknowledged various reasons for the loss of capability, and including:

a. a prolonged period of fiscal restraint in the 1990s;

b. a higher tempo of operations since 1998;

c. equipment continuing in service beyond its economic life;

d. a strong labour market affecting the ability to recruit and retain key personnel; and

e. a reduction in the Headquarters of the New Zealand Defence Force of support capabilities due to the high and pro-longed operational tempo.

The DCARR thus identified and quantified practical problems confronting the New Zealand Defence Force and the Ministry of Defence. The developing of appropriate expertise, experience and other desirable changes will take time in an organisation that is already actively engaged and employed in complex operations overseas. The armed services are inherently conservative and traditional - it is part of the military ethos. Change, if not properly explained and executed, runs the risk of producing unwelcome outcomes.

\section{The Defence Sustainability Initiative}

In May 2005, the government announced the Defence Sustainability Initiative (DSI). The purpose of this plan is to not only rebuild the New Zealand Defence Force to be able to produce the military outputs deemed necessary by the government's defence policy settings but also to improve corporate management within the Defence Headquarters itself. It gives material substance to the findings of the DCARR published a few months previously. The DSI is thus the latest measure in a long string of policy formulations to improve in all respects the contribution made by Defence to the government's policy objectives.
The most important part of the announcement concerned the investment of an extra $\$ 4.6$ billion in defence spending over a period of 10 years. This includes:

a. an increase of operating funding of $\$ 4.438$ billion (GST exclusive) for the New Zealand Defence Force over ten years from 2005/6;

b. capital injections of up to $\$ 209$ million over the period FY 2007/08 to FY 2009/10 (or later if the LTDP allowance is not exhausted by then) with a review of the appropriateness of this amount at the mid-term;

c. a permanent baseline increase of $\$ 0.844$ million (GST exclusive) from 2005/6 for the Ministry of Defence;

d. the Crown bearing the risk associated with the impact on depreciation of asset revaluations for the first five years of the DSI, reviewable at the midterm review of the DSI; and

e. a multi-year arrangement that allows for flexibility in the funding of operational deployments.

The DSI in many respects reiterates previous policy statements but in this case actually commits the Crown to provide the wherewithal. In other words, it provides funding certainty, a weakness identified several years ago in the government's Defence Statement of May 2001. Some proposals included in the plan underscore this contention, including:

a. strengthening the organisational and corporate capability of the Headquarters of the New Zealand Defence Force, and indeed the Ministry of Defence as well;

b. a new recruiting drive to lift personnel numbers;

c. the development of a New Zealand Defence Force real estate strategy; and

d. a programme to build up infrastructure including new IT capabilities.

The financial picture of the plan depicted in Figure 3 reveals a gradually increasing level of expenditure from 2005/06 for the next 10 years. This suggests a measured increase as more personnel are recruited, trained and reach the required levels of competence. 


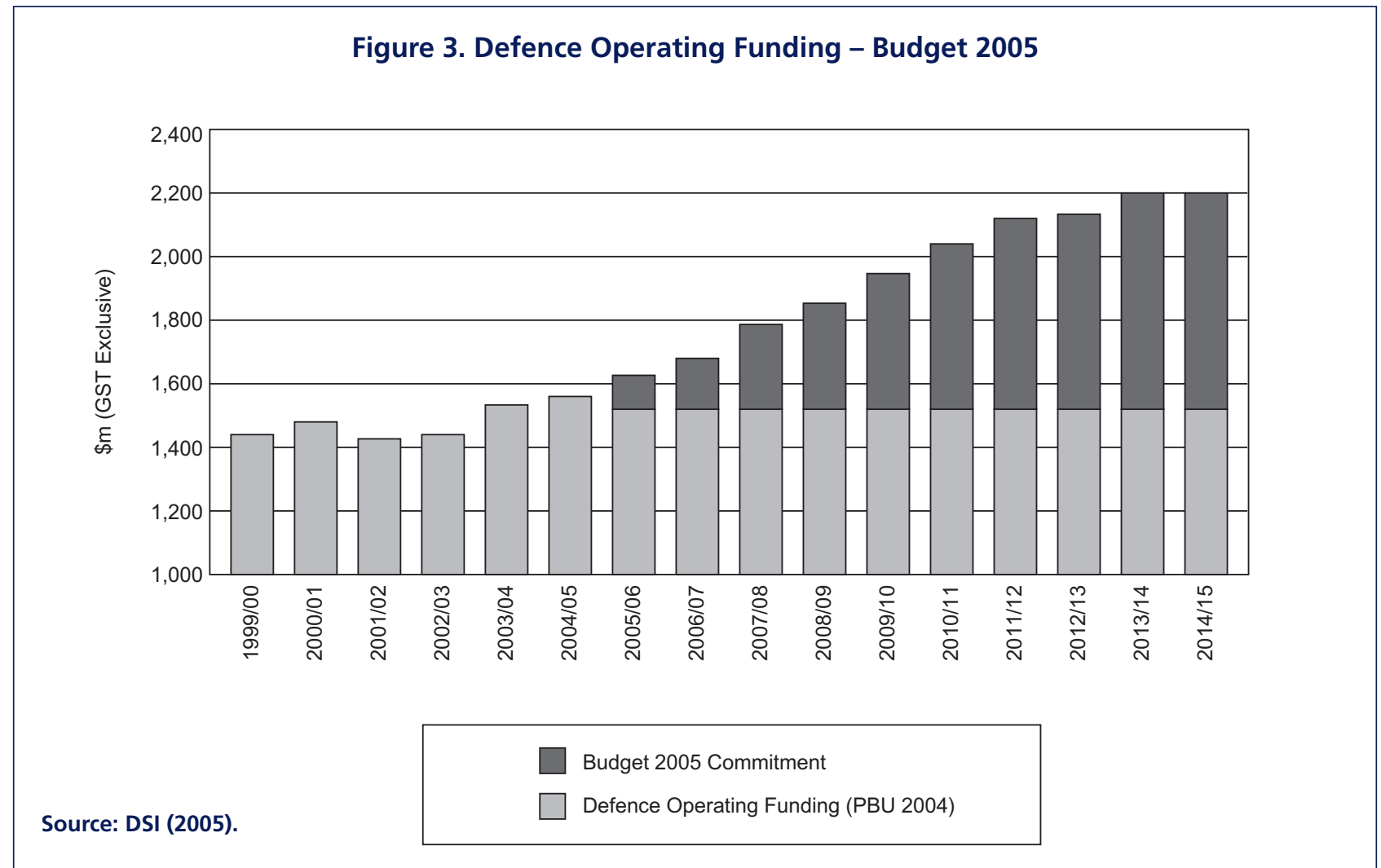

As part of the whole series of policy developments initiated by the Clark-led administration, future plans will include a new Strategic Plan and the expansion of the Defence Corporate Planning Framework to guide strategic management and to coordinate subordinate plans to integrate the management of personnel, infrastructure, equipment and resources.

\section{An alternative approach}

A significant expression of an alternative approach to Defence policy was published by the Royal New Zealand Returned Services Association in April 2005. It is a comprehensive survey and merits close study. Of particular importance the document states:

The development of defence policy in New Zealand has been an unnecessarily opaque process. Successive governments have failed to consult citizens adequately. Major reviews have been far too infrequent - the most recent White Paper was done in 1997, well before the events of September 11, 2001 changed our world. (RNZRSA 2005, p. ii)

This political criticism is not without validity. Getting the nation's defence strategy right is of critical importance within a broader schema to ensure collective security. A significant weakness in the Clark-led administration with respect to New Zealand's defence policy is that there has not been a Defence White Paper or major public review of defence during the past six years within an overarching review of national security. Nonetheless, the Minister of Defence (Burton, 2005, p.6), in an address to the International Institute of Strategic Studies at the Shangri La Dialogue in Singapore in June 2005, sought to dispel criticism of this omission and instead to suggest that there were differing policy-making approaches that worked just as well. He emphasised that the approach taken by the government was "carefully calibrated, publicised and debated in our open society, and circulated to our allies and friends". A differing approach is taken in Australia where the Defence White Paper 2000 addressed strategic policy which then guides defence policy. Following the events of 9/11 another review - Australia's National Security: A Defence Update 2003 - was released in February 2003. In the United Kingdom, The 1998 Strategic Defence Review was followed by the Defence White Paper in December 2003. Given the rapidly changing strategic environment, it is important that defence policy is continually reviewed. The White Paper process provides a suitable vehicle. 


\section{Conclusion}

The policy initiatives in Defence during the past six years offer substance, clarity of purpose and certainty. After substantial reductions in expenditure (in real terms) by previous administrations, plans and political commitment are now in place to rebuild the New Zealand Defence Force to provide an ability to meet future policy objectives. The various newly introduced corporate management and planning tools provide a robust foundation on which successive administrations will be able to build and alter capabilities as changing circumstances dictate. The adage by Confucius quoted at the beginning of this article remains germane.

\section{References}

Burton, Hon. Mark (2005) 'Defence White Papers, Transparency and Confidence Building', address to Shangri La Dialogue, Singapore, June.

Gentles, D. (2005) 'New Zealand Defence Policy: Has it been Transformed?' New Zealand International Review, 30(4).

Hunn, D. (2002) Review of Accountability and Structural Arrangements New Zealand Government, Wellington.

New Zealand Government (1987) Defence White Paper Wellington.

New Zealand Government (1990) The Defence Act Wellington.

New Zealand Government (1997) Defence White Paper Wellington.

New Zealand Government (2000) Defence Policy Framework Wellington.

New Zealand Government (2001) A Modern, Sustainable Defence Force Matched to New Zealand's Needs Government Defence Statement, Wellington

New Zealand Government (2002) Defence Long-Term Development Plan Wellington.

New Zealand Government (2005a) Defence Capability and Resourcing Review Wellington.

New Zealand Government (2005b) Defence Sustainability Initiative: Building a long-term future for the New Zealand Defence Force Wellington.

Quigley, D. (2000) An Enquiry into Defence Beyond 2000 House of Representatives, Wellington.
Royal New Zealand Returned Services Association (2005) Defending New Zealand Wellington.

Peter Cozens is the Director of the Centre for Strategic Studies in the School of Government at Victoria University of Wellington. He has a maritime and naval background and joined the Centre for Strategic Studies in 1995. He continues to nurture his fascination and understanding of Asia, in culture and civilisation, history, economics, civil society, music and the arts, and of course politics. 